\title{
PRESIDENTS AND THEIR SPEECHES AT NATIONAL COMMEMORATIONS
}

\author{
SAŠA BABIČ AND JURIJ FIKFAK
}

Presidents, prime ministers, and similar leaders occupy a special place among heroes and celebrities. They are special in many ways, not least because their privileged position, attained through a general or parliamentary elections, already places them at the center of public discourse. This allows them-and at the same time requires them - to express their opinions on a broad range of topics, events, and other issues. A previously "ordinary" individual suddenly becomes a central figure that determines which topics take priority, which discourses are politically correct, and so on. This article mainly focuses on analyzing the conceptual metaphors found in the speeches of four Slovenian presidents and selected leaders of other countries at various events, especially those involving state-building. Keywords: president, speech, discourse, conceptual metaphor
Med heroji in slavnimi osebnostmi imajo posebno mesto predsedniki držav, vlad ipd. Posebni so na več načinov, npr. s tem, da jih že njihov privilegirani položaj, na katerega so prišli po splošnih volitvah ali volitvah v parlamentu postavlja v središce javnih diskurzov. Na ta način jim omogoča in hkrati od njih zahteva izjavljanje o najrazličnejsih temah, dogodkih ipd. Včerajšnji "navadni" posameznik naenkrat postane osrednja figura, ki določa, katere teme so prioritetne, kateri diskurzi so politicno korektni itd. Osrednji fokus besedila avtorjev je analiza konceptualnih metafor $v$ govorih nekaterih tujih in stirih slovenskih predsednikov ob različnih, predvsem državotvornih ritualih.

Ključne besede: predsednik, govor, diskurz, konceptualna metafora

Presidents, prime ministers, and other leaders have a special place among the heroes and celebrities discussed in three publications (Jezernik 2013, Fikfak 2014, and Dan Podjed in this issue) issued as part of the Heroes and Celebrities ${ }^{1}$ research project. They are special in many ways, not least because their privileged position, attained through general (e.g., in Slovenia and Austria) or parliamentary (e.g., in Germany and Italy) elections, already places them at the center of public discourse. This allows them-and at the same time requires them - to express their opinions on a broad range of topics, events, and other issues. This is how an individual that was "just yesterday" a law professor, whose opinion was important only to a limited number of people (e.g., students), suddenly becomes a central figure that determines which topics take priority and which ones are secondary, which discourses are allowed, what is politically correct, and so on. Suddenly this role ascribes to him or expects him to have knowledge of everything; he has or is supposed to have an opinion and position on everything. All of this happens when he accepts the role, which is defined by the constitution and in most countries gives the selected (or elected) individual the right and obligation to be the country's commander-in-chief, to call general parliamentary elections; promulgate laws; appoint state officials as required by law; appoint and

1 These publications grew out of the research project Heroes and Celebrities in Slovenia and Central Europe J6-5558, led by Božidar Jezernik. 
recall the country's ambassadors and envoys, accept the credentials of foreign diplomatic representatives; amend the instrument of ratification; decide on granting clemency; confer decorations and honorary titles; and perform other duties determined by the constitution. In countries with a presidential system, such as the United States, this role is even more demanding, because the individual has to combine both roles: president of the country and leader of the government. He must represent the country on one hand and govern it on the other. The president must also be popular, considering that presidential terms are usually limited to four or five years and most countries allow election for only two terms (a total of eight to ten years). Much of his behavior is constrained by public expectations and his reelection prospects. Comparisons of presidents reveal certain difference between those that are directly elected and those chosen by parliament. Generally, the ones selected by parliament are more independent of public opinion in their positions and actions.

A president serves as the main official representative of his country abroad, and thus a position of authority in his country is implicitly ascribed to him, not only as the commanderin-chief of the military but also as the "leader of the nation." (cf. Carpenter 2016). After some years have passed this usually includes the role of the "father of the nation" as well. This role is especially enhanced by the fact that the parliament can charge him with taking a position on certain issues, the state of the nation, and so on. This involves expressing his opinion on important issues at important state-defining occasions; that is, inaugurations and state-building rituals (such as Independence Day, Statehood Day, and memorial events for partisans or victims of postwar killings). On the one hand, this position is granted by the election itself, and on the other, it realizes itself through a self-affirmative and selfreassuring capacity for self-presentation, something that is particularly evident in the current Slovenian president. There are words and actions that can only be relevantly uttered and carried out by the president, and in this regard his role is similar to that of a queen, who is the only one allowed to do certain things, such as christen a ship, which she does with the performative utterance: "I name this ship the Queen Elizabeth."

Why are presidents worthy of study? They are people in the limelight; as celebrities or heroes they also shape and transmit the value system; they are also largely selected or elected due to certain preferences that become evident in the time leading up to the election, when they define their election program and address the voters. Especially during election campaigns one can speak of a special interplay between both sides, in which the presidential candidates guess and try to define the tastes and expectations of their addressees (i.e., the anticipated electoral majority) and voters look at the candidates to find the individual that will fulfill their expectations and come closest to their ideological horizon. This description is necessarily simplified for the purposes of this paper and leaves out the media and polling agencies that also create the needs, desires, and to a certain degree also the "ideal president."

2 “'I name this ship the Queen Elizabeth'-as uttered when smashing the bottle against the stem." (Austin 1962) 
In countries where the parliament selects the president, the selection depends mostly on the parliament itself, and especially the relations between parties (e.g., in Germany). It is strategically oriented toward jointly seeking and electing a candidate acceptable to an absolute parliamentary majority - in these situations an individual with moral authority often wins. In contrast, in countries that directly elect their presidents, the choice generally depends most on the president's popularity and media presence. Thus, both presidential candidates and presidents themselves communicate with citizens using partially subliminal, mostly visual messages, such as from a stairway in Cairo, and also various "work gestures," but the primary way is with various linguistic messages, statements, and first and foremost, speeches.

Speeches are one of the numerous communication forms and practices used in a culture that is conceived as a multiplicity of communication processes, whether within the framework of Jakobson's (Lanigan 1991) or Lotman's (1994) theories of communication (the process of "coding and decoding"), whereby various receivers decode the sender's messages in a mostly habituated way. These processes are understood as semiosis, in which communication practices involve a complex system of signs either as icons, indexes, or symbols within Peirce's definition of semiosis or, in Carbaugh's simpler terms, communication as a system of symbols, symbolic forms, and their meanings (Carbaugh 2012: 74-76).

Faced with the impossibility of taking in the totality, human thought processes always refer to parts or particulars (Fikfak 2008), and so they are almost always metonymic and refer to the concrete details they originate from when people try to talk about the totality. The human conceptual system is thus metonymically or metaphorically structured and defined. "Our ordinary conceptual system, in terms of which we both think and act, is fundamentally metaphorical in nature" (Lakoff \& Johnson 1980: 3). Lakoff and Johnson argue that these concepts determine our everyday behavior, how we look at the world, and how we choose relationships or how we behave within them. Thus, the central role of our conceptual system and horizon is that of thought and action, but naturally language is the most important or primary source that orients and structures our conceptual world (Lakoff \& Johnson 1980: 3-6).

The particular communication process discussed here, presidential speeches, is also a metonymic metaphor for the (desired) relationship between the president and the people he is addressing: the public. A speech is a communication event, generally performed as faceto-face communication between an individual and an audience in a structured, deliberate manner for the purpose of communication intended to inform, influence, or entertain a listening audience. Speech includes knowledge, attitude, and ideology (van Dijk 2008); moreover, its language shows how the people understand abstract domains such as morality, politics, and so on.

Presidential speeches are one-way communication in which the speaker explains his ideas, knowledge, and attitude to the audience (i. e., citizens). This kind of speech is defined as a "speech act" (Austin \& Searle) or a "speech event" in ethnographic and anthropological 
studies; and it is motivated by a certain occasion: an institutionalized ritual practice. In a way is also prescribed and framed by this occasion. Capone states that only certain utterances can be expected and will thus be acceptable and that utterances should aim at something (their purpose) and be fulfilled if the purpose is taken up (Capone 2010: 2964-65).

Speeches can be understood as a means of creating authority and respect among a large group in our culture, such as the entire nation, with the characteristics of political speeches. This is the reason that political speeches are so frequently a part of national commemorations, where the president comments on current political and social events on the one hand, and expresses his ${ }^{3}$ vision of the future on the other. The question, however-and it is primarily connected with the media's role - is definitely the following: which portions of the speech are the audience able to grasp immediately, and which parts are received only after media use and interpretation (cf. Swanson, Jenkins, \& Jones 2016: 251-262)? Some parts of speeches gradually become independent quotations or independent metaphors (e.g., for independence and a warning of war: "Today dreams are allowed, but tomorrow is a new day").

One of the questions surrounding speeches is their authorship. This question became particularly pointed after the "Melania Affair," a controversy regarding a speech by the American president-elect's wife Melania Trump. It prompted the question of who had really written her speech and also the general question of who writes presidential speeches. In the Melania Trump situation it turned out that she did not write it herself, and that part of the speech was plagiarized from a speech by Michelle Obama. But even with Obama it turned out that she had not written it herself, but that it was the work of a very professional speech writer, Sarah Hurwitz, who had written it based on a thorough conversation with the First Lady. The polemics that some have developed into the debate about eastern and western concepts of education, authorship, and copyright point to something else. The president is generally not the sole author of the speech, but he authorizes it when he speaks it or reads it. The interview with Sarah Hurwitz illustrates how much potential there is for speakers to identify themselves with what is being spoken due to the dynamics of the speech's creation.

Of speeches written by the presidents themselves, it is worthwhile to look at Richard von Weizsäcker's "speech of the century" of 1985, given upon the fortieth anniversary of the defeat of Nazism. It was a speech that, to Germans, meant "the day of liberation from the inhumanity and tyranny of the National-Socialist regime."4 It is a speech in which the former German soldier, who had lost a brother in the first days of the war in Poland and later became a member of the coalition against Hitler, highlighted Germany's and Germans' collective responsibility for the evils of Nazism. The most important statements referred

All Slovenian presidents to date have been men, so we have chosen to use masculine pronouns.

4 “Die Große Trauer Richard von Weizsäcker: Der Präsident, den die Deutschen liebten.” See: http:// www.berliner-kurier.de/3061070@2017. http://www.lmz-bw.de/fileadmin/user_upload/Medienbildung_ MCO/fileadmin/bibliothek/weizsaecker_speech_may85/weizsaecker_speech_may85.pdf 
to the concept of personal responsibility, acceptance of the past ("All of us, whether guilty or not, whether old or young, must accept the past."), and the need for remembrance and reconciliation (“There can be no reconciliation without remembrance.").

One of the rare presidents to write his own speeches was Václav Havel. One of the main emphases in his early speeches was the need to accept the communist past, for which everyone was responsible in some way, whether members of the governing party or those governed. His exceptional competence as a writer allowed him to show the way toward tolerance and not only speak to Czechs and Slovaks in their joint country (1989-2003), pave the way for Czechoslovakia to split into two countries, and speak to Czechs in their own country later on (1993-2003), but also address the United States Congress and become one of the most important individuals worth listening to worldwide. It is clear, especially from a documentary film, ${ }^{5}$ that before every important appearance he carried out a dress rehearsal with an intimate group of staff. Havel was a perfect combination of various professions. These included a professional playwright, director, screenwriter, actor, opposition leader, and finally president of his country.

In Slovenia it is not entirely clear who writes the presidents' speeches. Interviews with people that have worked with some presidents, such as Milan Kučan or Danilo Türk, revealed that they requested analysis or texts for particular speeches; sometimes they used these analyses and sometimes not. However, textual analysis makes it clear that some speeches, such as the one in Kočevje Rog or the famous one from 1991 ("Today dreams are allowed, but tomorrow is a new day"), were almost certainly edited by Slovenian literary specialists, at least on the rhetorical level. In the specific case of Milan Kučan, it would be necessary to analyze and compare his speeches from the 1970s, in which the dominant conceptual metaphor was revolution ("Teachers are social workers for the League of Communists. The teacher is namely a soldier of the revolution"), and speeches from the 1990s, in which country, family, and the national interest were the dominant concepts. First, it would be necessary to check them and compare them to Katherin Verdery's study (1996) of the Romanian way of connecting communism and the national interest. Second, the potential for realistic conversion of positions should be examined, and third, the ability to make (micro)adaptations to the current political system and configurations of political and social power should be determined. This last point leads to the question of whose speech is read or given by the president. Is it his own or someone else's?

It is generally known who writes American presidents' speeches. The speechwriter has a professionalized function - there is even a speechwriting department that requests historical, political, and other analyses_-and he shapes the final text together with the president. In this case the president is a type of coauthor, which allows him to identify with the words he speaks. In John F. Kennedy's speech, which was mostly written by Ted Sorensen (2009), the main focus was on the relationship between duty and power. This 
is also the origin of his famous "and so, my fellow Americans: ask not what your country can do for you; ask what you can do for your country." The famous phrase, "Tear down this wall" uttered by Ronald Reagan was written by Peter Robinson (2003) after visits and discussions in Berlin itself.

Be that as it may, in the European setting the public generally does not know who wrote the speeches, who worked out the content of the utterance into its linguistic shape, who conceptualized it, and who originally wrote it. In each case one must conceptually anticipate different dynamics between the speaker and the text; it is a situation that Erving Goffman (2007) described with the term "footing," in which three roles are differentiated in relation to what a person says in spoken utterances. He can be either an animator, who simply reads and recites a script, or an author who composes and utters the words or a principal who is (makes himself) responsible for the expressed (read) statements.

Most speeches probably belong in the third category and for most presidents it is the desired impression and effect, as well as professionalization ${ }^{6}$ (or the refinement of the profession) that determines that speeches are written by a professional writer. Naturally, the special and central position that the speaker (the president) has at an event such as a statebuilding ceremony or inauguration requires him to largely identify with the things he says.

As the president animates the speech, he has to be committed to what the words express. He has to embody it; this is especially expressed in two ways. The general impersonal "it happens that" or passive position "one can witness" is contrasted with the active "we," which serves this personification. Because the president represents the country, he can also personify the citizens, using "we" in place of "I" in order to include more than the self. By using "we" the president uses his momentary position of a speaker to define the joint tasks that both he and the citizens in the audience must fulfill in order to achieve their set goals. ${ }^{7}$

Discourse analysis allows us to divide the concept of nodal points, which binds structuration elements into meaningful systems of moments, into discourse. Nodal points are signifiers or reference points in discourse; in discourse they bind together a particular system of meaning or "chain of signification" (Howarth et al. 2009: 8); for example, metaphorical words in the speech may reveal the president's deeper, even subconscious understanding of the state. At this point we can introduce conceptual metaphor as a building element in this "chain of signification."

6 The history of elections and election campaigns in Slovenia is a story of development and gradual professionalization. This is especially seen in the beginnings of democracy in Slovenia, in which the presidential candidates drove themselves to political rallies (e.g., Jože Pučnik and Ivan Kramberger), only had apparent support or voter bases (Ljubo Sirc), etc. The first stages of professionalization began with copying elections in other countries and also financial support. About presidents and professionals. Ie. experts wrote Lyons (2016).

7 See David Staker's analysis at http://changingminds.org/analysis/obama_victory_speech.htm for discussion of playing with pronouns and alternating between "I" and "we," along with animating the audience. 
Looking at different discourse levels in the usual way in presidential speeches we can observe positive self-presentation, positive topics about the nation, knowledge, beliefs, and attitudes, local meanings about positive actions, and rhetorical figures (hyperboles, euphemisms, metonymies, and metaphors).

\section{SELECTED SAMPLE}

This paper limits itself to and focuses on an analysis of some speeches by presidents and presidential candidates; they are texts that were prepared and read or recited at particularly special—nation-building-events, ${ }^{8}$ and so they are also generally the most wellthought-out and well-structured texts, in which the desired value system is also usually best defined. Using selected examples, we looked for what world and what values are transmitted, or intended to be transmitted, to the addressees (i.e., the people), and how the speeches appeal to them.

Our selection mainly considered speeches between 1991 and 2014, which are available on the Slovenian presidents' websites. The paper only theoretically samples inauguration speeches and those at significant national commemorations. The focus is on what metaphorical worlds presidents communicate to their citizens and what conceptual metaphors they use. The analysis sheds light on the conceptual map of the presidents' understanding of different "cornerstones" of the state and offers deeper insight to their understanding of the nation.

\section{PRESIDENTIAL SPEECHES}

The role of the country's president is to be the leader of the nation; in this regard, speeches at national commemorations represent a special communication practice with the public. This practice includes both a focus on the content and a specific articulation of wording, word figures, and language patterns; all of this creates both a vision of the country and establishes the image of a good leader and nation-keeper.

In this discourse analysis it must be emphasized that presidential speeches at national commemorations are generally the central feature, but nevertheless only part of the whole event. This means that they are only part of the screenplay and are formally subjugated to the writer and director. Their status is also cemented by protocol rules (Simonič 2009: 186): the red carpet, the official main focus on their speech, which is supposed to make an impression, and the listeners (citizens). Perception of the speech is ambivalent, however; some think that speeches are only a necessary and generally recognized part of a political 
ritual, whereas others that are the primary trendsetters in political discourse-generally political commentators - view them as the central part of the ceremony.

In any case, the problem is that the audience receives the speech very differently; many listeners do not listen to it at all, or only superficially. Naturally in such a context a speech is just part of protocol, a part of ritual practice carried out. The president is thus just a figure in the performance (Simonič 2009: 190); a figure that is an inescapable part of the show both for his symbolic significance and metaphorical authority. The protocol also includes the audience as part of the speech event, "adding and contributing to its text in a collaborative way (in particular, in constructing meaning)" (Capone 2010: 2966).

Yet another problem arises in listening to the speech. Although the aim of the speech is that it be noticed and perhaps even remembered by the listeners, they usually don't follow it attentively, mostly because it is performed in a monotone way: the president stands still and slowly reads the written text; his speaking is monotone and his posture is rigid; his gestures are minimalized to thoughtfully chosen small arm gestures; his affect is serious, his gaze is oriented toward the general listening public or to some object point in the hall; in essence, the one-way communication becomes impersonal. They maintain full control over their gestures, affect, voice, and words. This presentation style is the most common for Slovenian presidential speeches. Milan Kučan and Janez Drnovšek both especially embodied these characteristics. The monotone delivery results from the simple fact that there is limited eye contact with the audience, because the presidents read their texts from a sheet of paper. A different type of communication with the audience is displayed by American speakers (e.g., Barack Obama), or Václav Havel. The Obama uses a teleprompter, which helps the speaker especially at moments when he or she must transition from one mental and spoken passage to another. It allows a lively connection with the audience and the appearance of a dialogue. Stagecraft also aids the speaker in this regard, because it hides the teleprompter; in televised speeches the camera operators skillfully avoid showing the teleprompter.' Simply reading out a text has the effect of giving the written text the function of an independent third party to which both the speaker and the audience must refer. In this case identification of the speaker with the text and the audience reception are both less intense.

Another function of these texts is to show the president's sophistication in national (political and social) themes as well as in cultural dimensions, especially in the nation's literature. Presidents recall memories of events in their speeches, offering casual explanations or expressing their thoughts on them. Our analysis defines two main types of speeches by four Slovenian presidents: Milan Kučan (the first Slovenian president and, in that sense, the father of the nation), Janez Drnovšek, Danilo Türk, and Borut Pahor (the current president):

9 Barack Obama is known for extensive use of the teleprompter, but not his vice president Joe Biden. He said, "The standing joke in the office is Barack's learning to speak without a teleprompter, I'm learning to speak with one. I apologize for the teleprompter." http://www.huffingtonpost.com/2013/05/22/ joe-biden-obama-teleprompter_n_3319290.html 
1. Inauguration speeches, connected with taking the oath of office: with these speeches presidents confirm their suitability for the position at the inauguration ceremony in front of Parliament; because the ritual is also broadcast simultaneously on television, the oath and speech are also statements to the general public.

2. We have chosen speeches given at the national commemorations of Statehood Day and May Day because they reach the most citizens. They are a part of a large public event, performed on a decorated stage, which includes speeches from various people, music, dance, and readings of important Slovenian literary works. These celebrations are also broadcast on television and radio.

\section{INAUGURATION SPEECH}

Inauguration speeches are texts that are prepared for and read at the president's inauguration ceremony. ${ }^{10}$ The texts are presumably written by the presidents themselves. Taken as a whole, these speeches mainly contain perceptions of the country's future, visions, what should be done in the country during the president's mandate, a promise that the president will work within the limits of this vision, numerous ethical and friendly claims, and indications that he accepts the responsibility. The words of the oath are defined in the Constitution (Article 104), and reading them in front of the parliament is obligatory for all top officials: the speaker of the National Assembly, the prime minister, ministers, and of course the president of the country:

"I swear that I will respect the constitutional order and that I will act according to my conscience and with all my power for the good of Slovenia”.

Oaths contain many performative words (Austin 1962) in verbal utterance, as: $I$ promise (I swear). The performance utterance "was to be (or to be included as part of) the performance of an action" (Austin 1962: 60), which, of course, can be performed by an individual (i.e., the performer/future president).

At the time of the utterance, the performer must be doing something, although only in the active form of the verb in first-person singular or plural form: "there is something which is at the moment of uttering being done by the person uttering" (Austin 1962: 60). Presidents are promising some actions in future, which mean they obligate themselves to act in a certain way or to do certain things during their mandate. The circumstances of the spoken words should correspond in one way or another, and in many cases the speaker himself or someone else has to do some other physical or mental work, or even just continuing speaking and choosing words:

10 About presidential inaugural addresses see article by Chung \& Park (2010). 
I promise $=$ it is the case of doing something by saying it out with a word $\downarrow$

to say sth. = to do sth. $\rightarrow$ we do sth. when we say it out loud (Austin 1962: 19, 20).

Future presidents make a promise and take an oath; these have to be successful in that they remain true to their words. If they don't keep the word, the performative fails and they are perceived as somebody that will not do something (not that someone did not say the right thing or did not explain differently). This also means that:

Saying "I promise" compared to "I intend to" suggests crossing a certain threshold. Saying "I promise" is a socially accepted formula with which one binds himself to carrying out a particular action, and if the listener does not accept it as such, this places the promiser's position within social bonds in question (Žagar 2009: 15).

Presidential speeches and even oaths also apply to the listeners, because presidents will be one of them; president and citizens work together for the national welfare. Performative words in presidential speeches are in the form of first-person singular speech and are explicitly expressed only in presidential oaths during the act of promising. In this case the president promises personal responsibility. In other cases they are expressed in the first-person plural, because the whole nation is included in creating its future.

In their inauguration speeches presidents express their visions and plans for the future, points of focus, and their view of the country. The nature of this discourse requires a positive perspective on the history and state of the nation and an optimistic, affirmative attitude about the country's development. Slovenian presidents have stressed different points: Milan Kučan's focus was mostly on the independence process and the event of gaining a new state; Janez Drnovšek started to discuss ecology and the need to join the European Union and NATO, Danilo Türk's issue was a successful economy that increases the national welfare; Borut Pahor thematized crisis and looked for positive aspects of it, especially in the necessity of strengthening the collective spirit in dealing with difficulties.

\section{SPEECHES AT VARIOUS NATIONAL COMMEMORATIONS}

Speeches at most important national commemorations and the New Year's message reach most citizens, also because of radio and television broadcasts. The presidents use these speeches to uncover important domestic and global problems and challenges, and in addressing citizens they especially turn to issues that concern the "little guy."

All presidents speak as though they are one of many using the first-person plural form. Although the president is on stage and metaphorically on the pedestal of the highest authority in state, in these speeches he steps down to be one of common people, to make 
people believe that he sees and understands their problems. But at the same time he still maintains the voice of a moral and ethical pillar and gives guidelines regarding what is right and what is wrong.

Our duty is to create a community of public welfare and good-living people that encourages creativity and enriches the culture and spiritual life; we must be tolerant and respectful of others and we should seek truth from everyone, we must be sympathetic to the unfortunate and we should be ready to help ${ }^{11}$ (Milan Kučan: New Year's message, 1997).

... and from this symbolic square I appeal to everyone in Slovenia to a more responsible, more serious and deliberate dialogue ${ }^{12}$ (Danilo Türk, Statehood Day speech, June 24th, 2010).

Let us be decisive but tolerant. We will succeed ${ }^{13}$ (Borut Pahor, New Year's message, 2012).

Recurring speech themes include current national or state problems: politics, economics, employment issues, and so on, but nevertheless they also mention current events, such as important sports victories:

On these festive days we are even more proud. We are proud of our national soccer team, which is representing us so bravely and successfully at the FIFA World Cup ${ }^{14}$ (Danilo Türk, Statehood Day speech, June 24th, 2010).

All Slovenian presidents refer to great and well-known Slovenian poets in these speeches (Danilo Türk has the most quotes from Slovenian poets) as references to the current situation. Poets in that sense become oracles of the nation, and are consequently also (mis)used also for political discourses and intentions. Janez Drnovšek refers to France Prešeren as a great Slovenian poet in his inaugural speech (December 22nd, 2002):

${ }_{11}$ Na nas je, da ustvarimo skupnost javne blaginje in dobro živečih ljudi, da vzpodbujamo ustvarjalnost, bogatimo kulturo in duhovno življenje, da smo strpni in spoštljivi do soljudi in do iskanja resnice vsakogar, da smo razumevajoči do nesrečnih in smo jim pripravljeni pomagati (Milan Kučan: New Year's message, 1997).

12 ... in s tega simbolnega trga pozivam vse v Sloveniji $k$ bolj odgovornemu, bolj resnemu in premišljenemu dialogu (Danilo Türk, Official speech on Statehood Day, June 24th, 2010).

13 Bodimo odločni, a strpni. Uspeli bomo (Borut Pahor, New Year's message, 2012).

14 Te dni, ko praznujemo, pa smo ob praznovanju še dodatno ponosni. Ponosni smo na našo nogometno reprezentanco, ki nas tako srčno in uspešno zastopa na svetovnem nogometnem prvenstvu (Danilo Türk, Official speech on Statehood Day, June 24th, 2010). 
The great dream of a Slovenian poet, which we have adopted as a national hymn, here becomes a reality. ${ }^{15}$

I stand in the midst of life, said the poet ${ }^{16}$ (Milan Kučan, Festive Academy at the Independence Day, June 25th, 1998).

In Statehood Day speeches the last three presidents have referred to a famous phrase from Kučan's speech at the very first independence celebration on June 25th, 1991: "Today dreams are allowed, but tomorrow is a new day" (Danes so dovoljene sanje, jutri je nov dan); they generally repeat and create variations on the words dream and tonight.

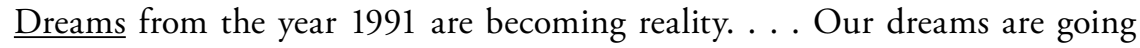
forward now. ${ }^{17}$ (Janez Drnovšek, speech on the eve of Slovenia's accession to the European Union, April 30th, 2004)

Here, at this historical place, our dreams of independence and full sovereignty for Slovenia came true. ${ }^{18}$ (Danilo Türk, Statehood Day speech, June 24th, 2008)

Tonight many participants of the War of Independence are among us . . . ${ }^{19}$ (Danilo Türk, Statehood Day speech, June 24th, 2010)

In this sense Kučan's speech from that historic day has become epic and it makes Milan Kučan into a higher authority than just as a president; after all, he was the first president of independent Slovenia.

In the following section we look at speeches by each president separately in order to reveal the main concepts and metaphors found in them. This analysis, limited to a few speeches, mostly shows each president's understanding of the concepts of nation, state, and citizens.

15 Veliki sen slovenskega pesnika, ki smo ga privzeli kot svojo državno himno, tako postaja resničnost (Janez Drnovšek, Inaugural speech, December 22nd, 2002).

16 Sredi življenja stojim, je dejal pesnik.

17 Sanje iz leta 1991 postajajo resničnost. . . Naše sanje grejo zdaj naprej (Janez Drnovšek, speech on the eve of Slovenia's accession to the European Union, April 30th, 2004).

$18 T u$, na tem zgodovinskem mestu, so doživele svojo uresničitev naše sanje o državnosti in polni suverenosti Slovenije (Danilo Türk, Statehood Day speech, June 24th, 2008).

19 Nocoj so z nami številni udeleženci vojne za Slovenijo ... (Danilo Türk, Statehood Day speech, June 24th, 2010). 
Milan Kučan (1941), the first president of Slovenia studied law at the University of Ljubljana. In 1968 he was the president of the Slovenian Youth Association, after that secretary of the Socialist Alliance of the Working People of Slovenia. By age 37 he was the speaker of the National Assembly, in 1982 the representative of the Slovenian Communists on the Yugoslavia League of Communists Central Committee; in 1986 he was the leader of the Slovenia League of Communists. After the Kučan-led Slovenian delegation left the Yugoslav Party Congress in 1990, the main ideological pillar of the Yugoslav idea and the one-party political system collapsed. The first multi-party elections were held in April 1990. Kučan was elected president of the Presidency, then a collective body, in 1990, in a ballot against the Demos candidate Jože Pučnik. On June 25th, 1991 Slovenia declared independence. Milan Kučan ended his speech with the words: "Today dreams are allowed, but tomorrow is a new day." Officially the next day (unofficially the same day), the Yugoslav army sent tanks to the borders with Italy and Austria, resulting in the Ten-Day War. Following international recognition of Slovenia, Milan Kučan was elected the first president of Slovenia in 1992 and later reelected in 1997. In his speeches the conceptual language is quite strong; he uses metaphors and many parallelisms and repetitions. Reading his speeches reveals that he is an omniscient narrator that knows what is good for the nation and is in a position that allows him to be the judge of the nation's maturity; for example:

Our citizens are mature people. And also understanding ones ${ }^{20}$ (Congratulatory remarks to the newly-elected government, December 8th, 2000).

Work is one of the most desirable characteristics and virtues, and is strongly expressed. He explicitly expresses that everything we achieve is result of work and persistence over time. Without work nothing would exist, our history would be meager, and we would not be an independent nation. Therefore, he exhorts listeners to also work hard in the future. Kučan usually talks about the nation, state, and citizens as though they are family. His conceptual metaphor nation $=$ family is strongly presented throughout all his speeches:

We are thinking about ourselves, about our loved ones, about our nation, about humankind ...21 (New Year's message from Milan Kučan, 1997).

The homeland is described as home:

. . . because they have the right to a country with equal opportunities for all, which will be both a democratic and tolerant house for all the diversity that

20 Naša javnost je zrela javnost. Je tudi razumevajoča (Congratulatory remarks to the newly-elected government, December 8th, 2000).

${ }_{21}$ Premišljamo o sebi, o svojih, o svojem narodu, o človeštvu . . . (New Year’s message, 1997). 
calls Slovenia home ${ }^{22}$ (Reception for members of the newly-elected government, March 6th, 1997).

We have our country. We should respect it and we should be proud of it. Let's do everything that needs to be done at home, so we can self-confidently adapt to the upcoming times ${ }^{23}$ (New Year's message, December 31st, 1999).

The comparative metaphor the state is like a living being has its context in the conceptual metaphor state $=$ child , because it is still growing up and developing:

The state is a living being . . . so that it will be respected at home and abroad and kind to all that live in it ${ }^{24}$ (Inauguration speech, December 22nd, 1997).

The country of Slovenia was born. It managed to live its own life ${ }^{25}$ (Statehood Day speech, June 25th, 1996).

The consolidation of the conceptual metaphor state $=$ family expresses itself in using metaphors that are typical of speech about marriage; a couple that is getting married is a couple that decides to take a common path:

The decision for an independent Slovenia was a decision for a common path ${ }^{26}$ (Statehood Day speech, June 24th, 2000).

This metaphor is even more pronounced in the phrase "For better or worse" (Speech at the Celebration of the Declaration of Independence, June 26th, 1991), which is taken from the wedding vow.

On the other hand, the conceptual metaphor state $=$ product, in which the common work of all citizens is stressed, can also be found:

... with the state, of which we are proud, because it is our shared work ${ }^{27}$ (New Year's message, 1997).

$22 .$. kajti pravico imajo do države, ki bo vsem dajala enako priložnost, ki bo skupna demokratična in strpna hiša za vse različnosti, ki so tu doma (Reception for members of the newly-formed government, March 6th, 1997).

23 Imamo svojo državo. Spoštujmo jo in bodimo ponosni nanjo. Doma postorimo, kar je treba, da bi se samozavestno prilagajala prihajajočim časom . . . (New Year's message, December 31st, 1999).

${ }^{24}$ Država je živo bitje ... da bo spoštovana doma in v tujini in prijazna do vseh, ki v njej živimo.

25 Slovenska država je bila rojena. Zmogla je svoje lastno življenje.

26 Odločitev za samostojno Slovenijo je bila odločitev za skupno pot.

$27 . . . z$ državo, na katero smo ponosni, ker je naše skupno delo. 
The equivalence of language/native language with identity is probably one of most common and general conceptual metaphors used in political language:

Responsibility for our language is responsibility for the nation's future. ${ }^{28}$ (Milan Kučan, Speech at the international symposium "Our Native Language at the Turn of the Twenty-First Century," December 2nd, 1999.

A person is made up of his native language ${ }^{29}$ (Milan Kučan, Speech at the sixty-fifth anniversary of the foundation of Slovenian Slavic Studies Society, June 7th, 2000).

Language is an expression of belonging to the nation and is one of the most obvious such expressions. After all, if a nation loses its language, it ceases to exist; a nation without a language cannot exist.

Time is an important word and category in Kučan's speeches, and his examples often follow a biblical model; he conflates time $X=$ time $Y$ : elections are times of confrontations / the time after an election is a time to cooperate and fulfill expectations. He also likes to repeat the word: "A new time has been running since then. A time of responsibility for it." 30 Time is the most commonly featured word in his speeches, which leads us to the obvious conclusion that Kučan feels that time is one of basic terms or categories of our existence.

In general, Kučan uses many parallelisms, multiple conjunctions, and metaphors. His language is rather poetic, although a closer reading of his texts reveals an emphasis on his expectations of various attributes from citizens, such as responsibility, collaboration, tolerance, and respect. Kučan gives instructions in speeches on how to behave and act in order to be a good politician or a good citizen. In metaphorical way he expresses his desire to be a leader that shows the right way for all citizens to be successful as a nation. He knows what the nation needs:

... Let's take this opportunity, which is worth to exploit. . . It is good for all of us to maintain really high expectations ${ }^{31}$ (New Year's message, 1998).

Kučan's sentence “Tonight dreams are allowed, but tomorrow is a new day" is generally the best-known political quotation in Slovenia. It is the title of the best-known political speech in Slovenia and also the concluding sentence of this very emotional speech, given on

28 Odgovornost za jezik je odgovornost za narodovo prihodnost (Milan Kučan, Speech at the international symposium "Our Native Language at the Turn of the Twenty-First Century," December 2nd, 1999).

29 Materni jezikje človekova vsebina (Milan Kučan, speech at the sixty-fifth anniversary of the founding of the Slovenian Slavic Studies Society, June 7th, 2000).

30 Odtlej teče nov čas. Čas odgovornosti zanjo.

31 ... Sprejmimo to priložnost, ki jo velja izkoristiti. . . . Dobro za vse nas je, da ohranjamo zelo visoka pričakovanja. 
June 26th, 1991 at the Celebration of the Declaration of Independence. The speech hails Slovenia's history and its efforts to become independent, its effort to preserve its language and culture; it proclaims Slovenia's openness and its friendly environment, and wishes for kindness, help, and cooperation.

The sentence "Tonight dreams are allowed, but tomorrow is a new day" has been used and modified many times, also by other politicians; for example:

- Borut Pahor modified it as a reference to Slovenia's independence into "Dreams are not only allowed tonight, they are necessary" 32 in his inaugural speech (December 22nd, 2013); and then again in his speech at the Statehood Day commemoration on June 24th, 2013: "On a cloudless evening twenty-two years ago we had a dream. Do we not have it anymore?"33

- Gregor Golobič used the sentence on October 6th, 2007 at foundation of political party Zares: "Today reality is allowed, tomorrow come new dreams." ${ }^{34}$ His modified version can also be interpreted as criticism, because "we cannot dream today, we have to start dealing with reality; after accepting reality we need new dreams."

Kučan's other important speech is "It is harvest time now" (Zdaj je čas žetve; June 25 th, 1996). The conceptual metaphor achievement $=$ harvest, to enjoy achievements $=$ harvest time is generally characteristic of Slovenian, but we cannot cite direct references from other politicians to this speech or to this quote.

Janez Drnovšek (1950) was born in Celje. While studying at the Faculty of Economics he traveled extensively and learned foreign languages. He earned a doctorate with a dissertation on Yugoslavia and the International Monetary Fund. He spent a year as a diplomat when he was 27, and at 36 he was a delegate to the Slovenian Republic Assembly and the Yugoslav Federal Assembly. In 1989 the local youth association in Zagorje selected him as a candidate for member of the joint presidency of Yugoslavia. Despite being a total outsider, he won, and at age 39 became the chair of the presidency. At the 200th anniversary of the French Revolution in Paris, he got to know leading Western statesmen, and in Belgrade he met non-aligned countries' statesmen. In 1990 he turned the chairmanship over to Borislav Jović, was involved in the negotiations with the Yugoslav People's army in 1991, and in 1992 when the Demos coalition fell apart he became prime minister, remaining in the position until 2002, when he became president of Slovenia. During his term Slovenia became a member of the European Union in 2004. Finally, a few years before his death in 2008, he founded the Movement for Justice and Development.

\footnotetext{
32 Nocoj sanje niso samo dovoljene, zdaj so nujne.

33 Na brezoblačni večer pred dvaindvajsetimi leti smo imeli sanje. Ali jih danes nimamo več?

34 Danes je dovoljena realnost, jutri so na vrsti nove sanje.
} 
Drnovšek did not emphasize the collective spirit in his speeches; there is no conceptual metaphor nation = family. He made a rather obvious distinction between the individual (and his/her life) and the nation, and at the same time his speeches partially recalled Kennedy's words regarding a citizen's duty to his country:

The new year is always also a time to evaluate everything achieved and new plans ... this is considered in our personal lives, at work, and also for the state, to which we belong and with which we would like to be in productive relationship. Through the state and its institutions we accomplish our common interests . . ${ }^{35}$ (New Year's message, December 30th, 2002).

Drnovšek uses the cognitive metaphor nation = ship:

... twelve years ago we were on the turbulent waves of history. We could have drowned, but we managed to swim. We could have been dragged into a big war, but we avoided it. We created our own country ${ }^{36}$ (Statehood Day speech, June 24th, 2003).

Going on with the speech, he talks about the state using the cognitive metaphor state = dwelling:

... to furnish it as well as possible, considering the experience and models of other, mostly European countries. Now we have to fill it with soul. Make it as pleasant to live in as possible. Because that is its purpose. ${ }^{37}$ (Statehood Day speech, June 24th, 2003).

For him the state is equivalent to people, citizens:

$$
\text { we are the state } \rightarrow \text { the state is } u s \rightarrow \text { state }=\text { people, citizens }
$$

In this connection it is important to mention the emphasis Drnovšek always placed on the fact that large social differences are a big problem, which gives value to the individual. He believed that politics were responsible for the state and the nation, and that politics

35 .. . novoletni čas je vedno tudi čas za oceno in presojo vsega doseženega in nove načrte. . . To velja za naša osebna življenja, za delo, ki ga opravljamo, pa tudi za državo, ki ji pripadamo in s katero želimo biti v tvornem interaktivnem odnosu, saj skozi njo in njene institucije uresničujemo skupne interese. . . .

36 ... pred dvanajstimi leti so nas nosili razburkani tokovi zgodovine. Lahko bi potonili, a smo splavali. Lahko bi se pustili potegniti v veliko vojno, a smo se ji izognili. Ustvarili smo svojo državo . . . .

37 .. . Jo čim bolje opremiti - ob upoštevanju izkušenj in modelov drugih, predvsem evropskih držav. Zdaj jo moramo napolniti z dušo. Jo narediti čim bolj prijazno za bivanje. Saj je v tem njen namen. 
could solve problems in the state. In that way he explicitly passed responsibility for the national welfare to the politicians.

Although Drnovšek started to separate the individual from the nation, he could not avoid the conceptual metaphor state $=$ child, wherein the nation is understood as a family, and discourse shifts from $I$ into we:

The country of Slovenia is celebrating its twelfth birthday . . . a young age for a country, but we had to be grown up already in order to obtain it ${ }^{38}$ (Statehood Day speech, June 24th, 2003).

Nevertheless, the biggest difference in Drnovšek's speeches is evident in his emphasis on the individual, equality, respect, problems of institutions that do not listen to the people, and he warns of the dangers of globalization. The concept metaphor nation = family is moved into the background and is not obvious any more. He emphasizes the importance of Slovenia's affiliation to the European Union and NATO, which (symbolically) represent security and place Slovenia in a wider context.

Danilo Türk (1952), born in Maribor, was the third president of Slovenia. He studied law in Ljubljana and obtained an MA in minority rights. As a professor he worked mainly in international law and human rights. From 1986 on he was associated with various UN commissions, and from 1992 on he was the permanent Slovenian representative to the UN. He published the first Slovenian book on international law in 2007. As a candidate backed by a coalition of leftist parties he won the election in 2007 against Lojze Peterle, who was supported by the right, and served as president until 2012. The same year he lost the election for President of Slovenia to Borut Pahor.

Work is a basic social value for Türk, and in that sense he approaches Kučan's view:

... that work always was, still is today, and will still be in the future a basic social value $^{39}$ (May Day Speech, May 1st, 2009).

The conceptual metaphor nation = family in Türk's speeches expands to become European nations $=$ family, which presents also security for our nation:

Our country has established itself in the family of European Nations ... ${ }^{40}$ (New Year's message, 2007)

38 Slovenska država praznuje 12. rojstni dan .. Rosna leta za državo, a morali smo dozoreti že, da smo jo dobili.

39 ..., da je delo vedno bilo, je danes in bo tudi v prihodnje temeljna družbena vrednota.

40 Naša domovina se je utrdila $v$ družini evropskih narodov.... 
His speech considers Slovenia as equal to all European nations, although there is the obvious implication that Slovenia is the one that needs Europe, not the reverse:

We need more Europe today, not less. ${ }^{41}$ (Statehood Day speech, June 22nd, 2012)

Another conceptual metaphor is state = payment for our work, of which we should be proud:

We have earned our own country. . . . Our pride is deserved. . . Our state is the payment for patriotism. ${ }^{42}$ (Statehood Day speech, June 24th, 2008)

Türk's speeches are rather precise and direct, with just a few proverbs or quotes from poets, which have the function of confirming the thought and including discourse about culture into discourse about economy and law, which remain main theme in his speeches.

Borut Pahor (1963) is the current Slovenian president. His mother was a Nazi concentration camp survivor. Pahor studied public policy and political science at the Faculty of Sociology, Political Science, and Journalism. He became a member of the Communist Party while in college in the early 1980s. In the late 1980s he was one of the strongest supporters of the more liberal, reformist wing of the party, along with Milan Kučan and Ciril Ribičič. During the JBTZ trial (1988) he proposed that the party renounce its ideological monopoly. Before 1990 he was the president of the League of Communists which, after the first free election in Slovenia, changed its name to the Social Democrats (1990-2012).

Borut Pahor served several terms as a member of the National Assembly and from 2004 to 2008 as member of the European Parliament. He is the only individual in Slovenia who has served in all three leading political offices in Slovenia, because he has been the Speaker of the National Assembly (2000-2004), prime minister (2008-2012), and president of Slovenia (2012-2017).

In 2012 he ran for the presidential election using a specific tactic: he took on numerous, varied roles of ordinary workers for one day (builder, upholsterer, and so on). ${ }^{43}$ The basis of this tactic for getting closer to the people was the motto "Together," which implicitly conveyed the message "I'm one of you." As president he saw himself as a problem-solver, as the one who could keep his campaign promises, and who would help people in times of crisis, when they want and need trust, respect, and tolerance. His escape route for resolving the crisis was cooperation, unity, collective work, concordance, altruism, and mutual help. He

41 Danes potrebujemo več Evrope, ne manj.

42 Lastno državo smo si zaslužili. . . Naš ponos je upravičen. . . . Država je plačilo za domoljubje.

43 See: http://www.primorski.it/stories/kultura/237096_pahor_predsednik_in_delavec/\#.WGqNDrGZPOQ 
used the metaphor of an unstoppable flood for the crisis, one that overflowed and spread across not only all of Slovenia but also Europe:

And then five years ago we suffered a severe crisis. All that was bad and wrongful was violently washed up to the surface. The only good thing about it was that the harmful consequences of transition were rudely exposed. ${ }^{44}$ (Statehood Day speech, June 24th, 2013)

The optimism is taken to the extreme: "Fortune favors the brave" 45 (Inauguration speech, December 22nd, 2012). Pahor also uses and paraphrases or even, when necessary, inverts some well-known phrases, especially from Milan Kučan; he transformed the passive, self-limited attitude ("dreams are allowed”) of Kučan's independence speech into a proactive position; that is, "dreams are necessary."

Dreams are not only allowed tonight, they are necessary. ${ }^{46}$ (Inauguration speech, December 22nd, 2012)

On a cloudless evening twenty years ago we had a dream. Do we not have it anymore? ${ }^{47}$ (Statehood Day speech, June 24th, 2013)

Both presidents (Kučan and Pahor) implicitly refer to Martin Luther King, Jr.'s Washington "I have a dream" speech; however, one uses it in a way that implies waiting: "what will happen tomorrow, when it's a new day?"

The presidents have one way or the other always addressed territory, whether the state or the homeland; in both examples they were usually not thinking of national or ethnic affiliation so much as the affiliation with a territory. Pahor returns to the conceptual metaphor homeland $=$ home, nation $=$ family to evoke patriotic feelings and to try to promote confidence in the future:

Our homeland - that is we are together as home and family ${ }^{48}$ (Statehood Day speech, June 24th, 2013).

\footnotetext{
44 Po tem pa nas je pred petimi leti doletela huda kriza. Vse slabo in zavržno je silovito naplavila na površje. Njena edina dobra stran je bila, da je surovo razgalila škodljive posledice tranzicije.

45 Sreča je na strani pogumnih.

46 Nocoj sanje niso samo dovoljene, zdaj so nujne.

$47 \mathrm{Na}$ brezoblačni večer pred dvajsetimi leti smo imeli sanje. Ali jih nimamo več?

48 Domovina smo mi vsi skupaj kot dom in družina.
} 
For him homeland is a broader term than state; "state" seems to be connected to the institution, while "homeland" is related to the nation, the country, its history, and patriotic feelings:

. . . and it isn't only about the state. It surpasses it. It is about homeland. ${ }^{49}$ (Inauguration speech, December 22nd, 2012, and again in the Statehood Day speech, June 24th, 2013)

He refers to patriotic feelings to evoke the need among citizens to keep Slovenia independent.

In practically every speech and also with a great number of concrete ritual practices, Pahor exhorts citizens and also politicians to tolerance, political patience, and maximum mutual understanding. ${ }^{50}$ His most recent speeches, especially the one about the victims of the extrajudicial killings at Huda Jama, are based on reconciliation and inclusive strategies, which rely on the piety toward all the dead: "This memorial serves the dead and, in equal measure, the needs of the living. It is a memorial and a reminder." ${ }^{11}$ The metaphorical framework of reflection and action is the homeland, as in Župančičs verse, "We are only given one homeland and one life and one death." 52

\section{CONCLUSION}

The president of the state, both in Slovenia and elsewhere, is one of the most visible and representative individuals in the country. They represent a moral and ethical pillar, and they are perceived as a moral and ethical role model for citizens. All these "ideal attributes" are expressed in their speeches at national commemorations, where on the stage they play the role of the leader of the nation. It is obvious that the function of these speeches is to use the symbolic power of language (Bourdieu 1991) to influence the citizens and to establish authority.

The material analyzed makes it obvious that presidents try to evoke patriotic feelings with the concepts that nation is family, our homeland is our home; we are on the same boat and we should work as a collective, hand in hand, and take care of each other, as a truly healthy family would.

49 .. . in ne gre samo za državo. Gre za presežek tega. Gre za domovino.

50 ... da bi ta nehvaležen čas do oblikovanja nove vlade potekal v vzdušju strpnosti, politične potrpežljivosti in čim večjega medsebojnega razumevanja (Speech on May Day, May 1st, 2014).

51 See: http://www.up-rs.si/up-rs/uprs.nsf/objave/58F233037B1B2633C1257E6D005B02C6?OpenDo cument

52 Domovina je ena nam vsem dodeljena, in eno življenje in ena smrt (Oton Župančič). 
Presidents are ascribed the role of an authority. They highlight the problems and solutions, and know what is right and wrong. In this regard, their discourse can be interpreted as paternalistic or omniscient.

However, their practices are largely received ambivalently or polyvalently. On the one hand they are defined by the fact that the president is pretty much always still a member of a particular party; all four Slovenian presidents so far have been left-oriented (within the Slovenian perception of left vs. right). Within this framework they were usually received with reservations by the right-leaning members of the public. The most controversy has surrounded the current president, who even in his election campaign made use of a different form of communication with the public, which he is continuing during his presidency. His attitude has eroded the established considerations of what is and how someone should be president. The practices, behavior, and speeches of President Borut Pahor are thus generally accepted ambivalently. Primarily this concerns the issue of the president's role, which today is somewhere between "leader of the nation," "ordinary citizen," and "celebrity." This is also why the question of the real power and effect of presidential speeches or speech acts has remained central.

\section{SOURCES}

http://www.bivsi-predsednik.si/

http://www2.gov.si/up-rs/1992-2002/mk.nsf/1992-2002/index.html (speeches of Milan Kučan)

http://www2.gov.si/up-rs/2002-2007/jd.nsf (speeches of Janez Drnovšek)

http://www2.gov.si/up-rs/2007-2012/turk-slo-arhiv.nsf (speeches of Danilo Türk)

http://www.up-rs.si/up-rs/uprs.nsf/medijsko-sredisce?OpenView\&RestrictToCategory=govori (speeches of Borut Pahor)

\section{REFERENCES}

Austin, John L. 1962. How to do Things with Words. Oxford: Clarendon Press.

Bourdieu Pierre (1991) Language and Symbolic Power. Ed. Thompson John B. Trans. Raymond Gino, Adamson Matthew. Cambridge, MA: Harvard University Press.,

Capone, Alessandro. 2010. Barack Obama’s South Carolina Speech. Journal of Pragmatics 42 (2010): 2964-2977.

Carbaugh, Donal 2012 A Communication Theory of Culture. SelectedWorks of Donal Carbaugh. http:// works.bepress.com/donal_carbaugh/28,69-87.

Carpenter, Dick M. II. 2016. Presidents of the United States on Leadership. Leadership, 3 (3): 251-280. DOI: $10.1177 / 1742715007079307$ http://lea.sagepub.com 
Chung, ChungJoo \& Han Woo Park. 2010. Textual analysis of a political message: the inaugural addresses of two Korean presidents. Social Science Information 49 (2): 215-239. DOI: 10.1177/0539018409359370 http://ssi.sagepub.com

Fikfak, Jurij. 2008. Med delom in celoto. Nekatera vprašanja etnološkega raziskovanja in reprezentacije. (Between Part and Whole. Issues in Ethnological Research and Representation.) Traditiones 37(2): 27-44. DOI: 10.3986/Traditio2008370202

Fikfak, Jurij. 2014. Leaders of the nation. (Heroji, vodje naroda). Traditiones 43(1): 7-11. DOI: 10.3986/ Traditio2015430101

Goffman, Erving. 2007. Footing. In: Monaghan L., Goodwin J.(eds.). Voicing: Reported Speech and Footing in Conversation. Cambridge: Cambridge University Press, 396-400.

Howarth, D., Norval, A. J., Stavrakakis, E. Y. 2009 Discourse theory and political analysis. Identities, hegemonies and social change. Manchester University Press.

Jezernik, Božidar (ed.). 2013. Heroji in slavne osebnosti na Slovenskem. Ljubljana: Znanstvena založba Filozofske fakultete.

Lakoff, George and Mark Johnson, 1980 Metaphors we Live by. Chicago, London: The University of Chicago Press.

Lanigan, Richard L. 1991. Roman Jakobson's Semiotic Theory of Communication. https://eric. ed.gov/?id=ED355570

Lotman, Jurij M. 1994. Universe of the Mind. A Semiotic Theory of Culture. Bloomington, IN: Indiana University Press.

Lu, Wei-Lun Louis \& Kathleen Ahrens. 2008. Ideological influence on BUILDING metaphors in Taiwanese presidential speeches. Discourse \& Society, 19 (3):383-408 DOI: 10.1177/0957926508088966

Lyons, Gene M. 2016. The President and His Experts. The ANNALS of the American Academy of Political and Social Science, 394 (1): 36-45.

Robinson Peter (2003. How Ronald Reagan Changed My Life. New York, NY: Regan Books.

Simonič, Peter. 2009. Kaj si bo narod mislil?: ritual slovenske državnosti. Ljubljana: Znanstvena založba Filozofske fakultete.

Sorensen, Ted. 2009. Counselor: A Life at the Edge of History. New York, NY: HarperPerennial.

Swanson, Charles E., James Jenkins, Robert L. Jones. 2016. President Truman Speaks: A Study of Ideas vs. Media. Journalism \& Mass Communication Quarterly 27(3): 251-262. DOI: 10.1177/107769905002700301

Van Dijk, Teun A. 2008. Discourse and Context. A Sociocognitive Approach, Cambridge: Cambridge University Press.

Verdery Katherine. 1996. What Was Socialism, and What Comes Next? Princeton, NJ: Princeton University Press.

Žagar, Igor Ž. 2009. Od performativa do govornih dejanj. Ljubljana: Pedagoški inštitut (Digitalna knjižnica. Dissertationes). http://tinyurl.com/zdmjlvb 


\section{PREDSEDNIŠKI GOVORI OB DRŽAVNIH SLOVESNOSTIH}

Med heroji in slavnimi osebnostmi imajo posebno mesto predsedniki držav, vlad ipd. Posebni so na več načinov, npr. s tem, da jĭh že njihov privilegirani položaj, na katerega so prišli po splošnih volitvah ali volitvah v parlamentu postavlja v središče javnih diskurzov. Na ta način jim omogoča in hkrati od njih zahteva izjavljanje o najrazličnejših temah, dogodkih ipd. Včerajšnji "navadni" posameznik naenkrat postane osrednja figura, ki sporoča, katere teme so prioritetne ali sekundarne, kateri diskurzi so politično korektni, kateri nezaželeni itd.

Eno osrednjih vprašanj je možnost vpliva konkretnega govora na naslovljene publike. $\mathrm{Na}$ eni strani se zdi, da so govori kot del rituala, neogibni, sestavni del državne slovesnosti in kot taki le ilustracija trenutnih pogledov na razmere $v$ državi, ... Vendar pa labko nekateri govori, še posebej v ključnih trenutkih, vplivajo na splošno dojemanje in morebitno prevrednotenje in preusmeritev pogledov. Med govori, ki so bistveno vplivali na nadaljnje dogodke labko štejemo govor Hruščeva leta 1956, Kennedyev govor o dolžnostih državljanov 1960, Havlov govor o stanju v državi leta 1989; prav tako je Kučanov govor junija 1991 bistveno zaznamoval čas slovenskega osamosvajanja. Predsedniški govori labko spodbujajo evroskepticizem (Vaclav Klaus) ali Evropo kot edino možnost in priložnost (Havel, Drnovšek).

Osrednji fokus besedila avtorjev je vzorčna analiza konceptualnih metafor v govorih nekaterih tujih in štirih slovenskih predsednikov ob različnih, predvsem državotvornih ritualih. Iz analize gradiva je očitno, da da želijo predsedniki prebujati domovinsko čustvovanje s koncepti naroda kot družine, in domovine kot lastnega doma; vsi smo na istem čolnu, delati moramo $z$ roko $v$ roki, skrbeti drug za drugega - tako kot to dela prava zdrava družina. V tem okviru si predsedniki zagotavljajo avtoriteto, poudarjajo, katere so težave, kje so rešitve, in vedo, kaj je prav in kaj ni.

Vsekakor pa so njihove prakse v veliki meri sprejete ambivalentno ali polivalentno. $N a$ eni strani so definirane s tem, da predsednik skoraj praviloma še vedno pripada določeni stranki; vsi štirje slovenski predsedniki doslej so bili praviloma levo (znotraj slovenskega koncepta levo - desno) orientirani; $v$ tem okviru so bili na strani desno orientirane publike $v$ najboljšem primeru sprejeti z zadržkom. Najbolj pa se polemike kažejo in sprožajo ob prvem in zadnjem predsedniku; ob prvem, za katerega nekateri pišejo, da je najvplivnejši upokojenec in da nikoli ni zares odšel, ${ }^{53}$ in ob drugem, ki je že v svojem volilnem boju naznanil drugačne oblike komunikacije z javnostjo, in ki to nadaljuje tudi v samem predsedovanju. S svojo držo je načel uveljavljene razmisleke o tem, kaj in kako naj bo nekdo predsednik. Prakse, ravnanja in govori predsednika Boruta Pahorja so tako v veliki meri sprejeti ambivalentno. Predvsem gre za vprašanje o vlogi predsednika, ki je danes med položajem "vodje nacije”, "običajnim človekom"

53 A. K. K., M. K. Milan Kučan - predsednik, ki ni nikoli zares odšel. Predsednik, ki je Slovenijo popeljal na pot samostojnosti. http://www.rtvslo.si/predsedniske-volitve-2012/ milan-kucan-predsednik-ki-ni-nikoli-zares-odsel/293461 
in "zvezdnikom". Tudi zato ostaja temeljno vprašanje o realni moči in učinku predsedniških govorov oz. govornih dejanj.

Assist. Prof. Saša Babič, Institute of Slovenian Ethnology,

SRC SASA Ljubljana, Slovenia, Sasa.babic@zrc-sazu.si

Assoc. Prof. Jurij Fikfak, Institute of Slovenian Ethnology,

SRC SASA Ljubljana, Slovenia, fikfak@zrc-sazu.si 